RESEARCH ARTICLE

\title{
Citizens Without Robes: On the Deliberative Potential of Everyday Politics
}

\author{
Simone Chambers
}

This essay is a sympathetic critical comment on Cristina Lafont's recent book, Democracy without Shortcuts: A Participatory Conception of Deliberative Democracy. I focus primarily on the arguments in the final chapters of the book that introduce a deliberative democratic re-interpretation of judicial review. Lafont appeals to the evocative imagery of citizens in robes and suggests that contesting legislation at the level of the supreme court does not take questions out of the public sphere and into the legal domain but rather brings questions of right and constitutionality into the political domain. The institutional possibility for individual citizens to challenge any law and thus launch a broad public debate that demands justifications and reasons is the heart of Lafont's conception of participatory deliberative democracy. I find this a powerful and compelling defense and understanding of judicial review. I question, however, what appears to be a narrowing of deliberative democracy to constitutional contestation and so an abandonment of everyday politics where issues, debates, and controversies are not structured by the constraint of constitutional discourse. I argue that the focus on constitutional politics, made necessarily by her public reason requirement, narrows the range of her theory and appears to leave everyday politics outside the scope of deliberative democracy.

Keywords: deliberative democracy; judicial review; public reason; self-government; public sphere; constitutional rights

\begin{abstract}
Introduction
The crisis of democracy has produced a new wave of innovative forward-looking democratic theory. Cristina Lafont's book, Democracy without Shortcuts: A Participatory Conception of Deliberative Democracy is part of this extraordinary wave of democratic theory that seeks to revitalize and strengthen our ideal of democracy rather than lament the precariousness of our predicament. The book focuses on the question-is self-government a coherent ideal?-and reconstructs a deliberative democratic interpretation of democratic self-government that is both realistic at the same time as hopeful. Lafont claims that she is not offering a full defense of democracy for skeptics (although many arguments in the book do exactly that). Instead she is taking the value of democracy as a giving and then challenging the way many contemporary theorists cash out that value. Her central complaint is that much of contemporary democratic theory by-passes real citizens in favor of institutions that speak in the name of citizens rather than allowing, indeed insisting, that citizens speak for themselves. Theories that call on majorities, (unresponsive) representatives, experts,
\end{abstract}

University of California Irvine, US

sechambe@uci.edu and minipublics to speak on behalf of citizens come under criticism for proposing shortcuts that side-line the long and sometimes difficult road of getting citizens themselves to engage in a type of deliberation that can hold public actors and institutions democratically accountable. Thus in contrast to shortcuts that forego real citizen participation, Lafont defends the long way around of a participatory conception of deliberative democracy.

The conception of participation advanced in this book differs in significant ways from more traditional views of participatory democracy. First of all, it is participation in public debate and discourse (opinion and will formation) rather than the more traditional categories of voting, protests, marches, civil society engagement, and political activism. But more significantly, the book ends with an extended discussion and defense of a very particular type of participation: individual citizens challenging laws in constitutional courts. The idea here is that when citizens challenge the constitutionality of laws they are asking for a justification of those laws. Thus legal activism is to be understood in discursive or deliberative terms as an extension of and indeed instantiation of democracy. Legal challenge ideally initiates a broad public debate that could and hopefully would include citizens at large. On this view then the legal activism of the civil rights movement, for example, could be seen as launching an 
extended process of public opinion and will formation in the hope of producing a new and more adequate shared understanding of civic equality. Lafont's vision of participatory deliberative democracy culminates in a powerful and compelling democratic re-reading of constitutional politics. The institutional possibility that individual citizens can challenge any law and thus launch a broad public debate that demands justifications and reasons is the heart of the participatory claim.

Lafont offers an inspiring and powerful view of deliberative democracy and there are many parts of the argument that I find deeply compelling. But there are also parts of the argument that seem to me problematic as a full picture of deliberative democracy. In what follows, I focus on the final chapters of the book. These chapters lay out the relationship between democracy and constitutional courts especially the institution of judicial review-the power of courts to review democratically enacted legislation. Although I find Lafont's democratic re-reading of judicial review brilliant, I am less taken with her constitutionally focused re-reading of deliberative democracy. I begin with what I think are the strongest parts of this argument, namely the democratic legitimacy of judicial review. Here I compare her view to two other justifications of judicial review from a deliberative point of view and show how she combines the best of these views into her own. I then turn to the claim that judicial review furnishes an important perhaps paradigmatic institutional opportunity for the exercise of participatory deliberative democracy. I argue that the focus on constitutional politics, made necessarily by her public reason requirement, narrows the range of her theory and appears to leave everyday politics outside the scope of deliberative democracy.

\section{Constitutional Contestation as Participatory Deliberative Democracy}

In Democracy without Shortcuts, Lafont introduces an innovative and powerful democratic defense of judicial review. Within democratic theory generally, judicial review has often been thought of as a counter majoritarian institution designed precisely to limit and hem in democratic self-government. For some, this has led to a deep suspicion of courts and their role in democracies. There are a number of versions of that suspicion from ideas of political constitutionalism (Bellamy 2007; Waldron 2006) and popular constitutionalism (Tushnet 2000; Kramer 2004) but also a growing recognition of populist constitutionalism. ${ }^{1}$ Deliberative democracy has generally been less bothered with the so called countermajoritarian tendencies of judicial review and has for the most part not taken a suspect view of judicial review. There are two main grounds for supporting judicial review from a deliberative perspective. I call the first, the argument from public reason and the second, the argument from public discourse. Lafont introduces a third argument that draws elements from both the public reason view as well as the public discourse view. Let me begin then with the public reason view.

Many but not all deliberative democrats endorse an idea of public reason as an essential part of democratic deliberation. As Lafont is one of those theorists (and I am not) and this will come up again further on in this essay, it might be worthwhile to take a moment to say a few words about public reason although by now it is a very familiar concept. All deliberative democrats endorse some version of Rawls' idea of public justification. Public justification, Rawls tells us, 'is not simply valid reasoning but argument addressed to others' (2005: 465). We show respect for the free and equal status of our fellow citizens when we approach the justification of laws and policies as mutual justification in which we speak to and address each other's concerns, interests, and priorities. But when it comes to determining more precisely what those reasons and justifications might look like, there is a great deal of disagreement. At one end of the spectrum are political conceptions of justification that are open ended, process or procedurally based, and resist any set determination of what a public reason is in advance. These views also tend to down play or outright reject consensus as the end of deliberation. I consider the work of John Dryzek (2010), Jane Mansbridge (1999), and Mark Warren (2007) (to name only a few) as well as my own work (Chambers 2017) to fall into this group.

At the other end of the spectrum are theories that follow Rawls and Joshua Cohen and think of public justification in moral/epistemic rather than political terms. Appropriate reasons are reasons we share, and it is only by drawing on these sorts of reasons that we will be able to come to agreements that can then underwrite the legitimacy of laws. Thus on this view deliberation involves a significant constraint on reasons. ${ }^{2}$ Rawls' view of public reason evolved over time beginning with a relatively restrictive idea that excluded all appeal to comprehensive views of truth or the good and then expanding to allow for the articulation of comprehensive views in public justification as long as there were properly public reasons (shared and neutral) available. Gutmann and Thompson incorporate this idea into their conception of deliberative democracy by insisting, for example, that citizens 'appeal to reasons or principles that can be shared by fellow citizens ... moral reasoning is in this way mutually acceptable' (1996: 55).

Habermas falls somewhere in the middle depending if one stresses the procedural and political elements of his theory or the consensual and moral elements. Public justification for Habermas is 'ultimately based only on reasons that withstand objections under demanding conditions of communication' (2008: 49). ${ }^{3}$ On this view then, it appears as if we cannot stipulate in advance what reasons will pass this test. Furthermore, the political public sphere is under no constraint and anything may be introduced into debate. This is not because there is no hope of agreement or finding reasons we share but because shared reasons need to be constructed in the procedure itself and we cannot always predict what these may be. Thus for Habermas one might say that public reasons are the outcome rather than input of public debate.

To return to the question of judicial review, Rawls famously suggested that supreme or constitutional courts are exemplars of public reason. '(I)n a constitutional regime with judicial review, public reason is the reason of its supreme court' (2005: 231). Although Rawls notes that legislators and ordinary citizens are under some obligation 
to appeal to public reason, he also acknowledges that both these groups are faced with many political questions for which more partisan, interested, or comprehensive forms of reasoning may very well be appropriate. A supreme court, by contrast, is tasked with impartiality and neutrality of a special kind.

On the public reason view then, courts that exercise judicial review should not be seen as opponents to or limits on democracy but as the highest or purest expression of how citizens themselves ought to be (but often are not) deliberating. This view is sometimes taken so far as to suggest that citizens and legislatures are often incapable of meeting the high bar of public reason. For example, in the essay 'Constitutional courts as deliberative institutions' John Ferejohn and Pasquale Pasquino suggest that public reason is the defining feature of good deliberation and courts are the only place to find that type of deliberation. 'John Rawls described courts as exemplary deliberative institutions - forums in which reasons, explanations, and justifications are both expected and offered for coercive state policies' (Ferejohn \& Pasquino 2002: 22). They argue that deliberative expectations diminish as one moves from courts to public agencies, legislators, and then finally voters. The ballot box is a 'reason-free zone' where citizens do not have to have nor are they expected to give reasons for the votes (2002: 26; see, Mendes 2013: 93). Ferejohn has also noted that 'deliberative expectations are inversely correlated with democratic pedigree' (2008: 206).

Christopher Eisgruber also argues that a supreme court has a special role to play in democratic deliberation. A supreme court, he says, "is a kind of representative institution well-shaped to speak on behalf of the people about questions of moral and political principle' (Eisgruber 2001: 35). In a critical assessment of this type of deliberative defense of courts and judicial review, Christopher Zurn sums up these arguments this way: 'Constitutional courts then because they speak in the language of the people's public reason and because they are the institutional representations of the people's public reason, are in fact eminently democratic actors, even when they are legislating new constitutional content' (2020: 326). A supreme court is 'uniquely qualified to represent the people's principles because of its specially heightened capacities for reasoned deliberation about fundamental moral-political matters' (Zurn 2020: 335).

Conrado Hübner Mendes takes a more nuanced view than Eisgruber in defending judicial review on deliberative grounds, in particular he does not see the adherence to public reason as the defining quality of a good deliberative credentials: 'an ideal-type deliberative court ... is one that maximizes the range of arguments from interlocutors by promoting public contestation at the pre-decisional phase; that energizes its decision-makers in a sincere process of collegial engagement at the decisional phase; and drafts a deliberative written decision at the post-decisional phase' (Mendes 2013: 107). Although Mendes sees 'promoting public contestation' as a central feature and function of good deliberative courts, like Eisgruber he focuses on something special about the deliberation of judges.

The second strategy to defend judicial review from a deliberative point of view, what I call the argument from public discourse, argues that these courts have a special task of facilitating and protecting democratic deliberation. Rather than focusing on slapping down substantive outcomes that violate the constitution and so setting themselves against democratic self-government, this view sees a special role for the court to facilitate citizen deliberation and exercises of democracy both at the broad participatory level as well as the level of representative legislatures. Habermas notes 'a rather bold constitutional adjudication is even required in cases that concern the implementation of democratic procures and the deliberative form of political opinion-and will-formation' (1996: 279-80; Zurn 2007 also endorses this view). Courts do not speak for the people; courts and judicial review are essential to allow the people to speak for themselves. Although discourse about constitutional controversies is an important element of public deliberation, the public discourse view in contrast to the public reason view, sees courts as structuring and safeguarding democratic procedures more generally. The public reason view sees debate and deliberation about basic structure and constitutional essentials as where all the important deliberative action takes place. Furthermore, the public discourse view is careful not to overstate the quality of deliberation in the courts as opposed to legislatures and is not premised on the argument that legislatures are poor and untrustworthy deliberators. Finally, rather than seeing courts as a limit on majorities, the public discourse view sees courts as creating the procedural conditions that confer legitimacy on majorities. The strongest version of this argument can be found in Habermas co-originality thesis in which constitutionally protected rights and democratic opinion and will formation are in a tight reciprocal relation of interdependence (1996: 118-122).

Christina Lafont adds a third argument that stands somewhere between these two. Like Ferejohn and Eisgruber she thinks that deliberative justification calls for public reason and so a great deal of everyday politics will not rise to this level. Deliberative justification has a special role to play when we are deciding constitutional questions. But unlike Ferejohn and Eisgruber, and more like Habermas and Zurn, she does not think that judges deliberate on behalf of citizens but rather citizens themselves engage in constitutional deliberation. While it might appear that legal activism takes questions out of the public political sphere and sequesters them in the closed halls of Supreme Court adjudication, Lafont argues that this is a mistaken picture. 'In constitutional democracies with judicial review, the right to legal contestation guarantees that all citizens can, on their own initiative, open and reopen a deliberative process in which reasons and justifications aimed at showing the constitutionality of a contested policy are made publicly available, such that they can be scrutinized and challenged with counter arguments that might lead public opinion to be transformed and prior decisions overturned. Citizens' right to question constitutionality of any policy or statute by initiating legal challenges enables them to structure public debate on the policy in question as a debate about fundamental rights and freedoms and therefore as a debate in which the priority of public reasons (with its 
corresponding standards of scrutiny) must be respected' (2019: 212-13).

This is a powerful argument that turns the tables on so much of the debate about judicial review as that debate focuses exclusively on judges and forgets that it is citizens who bring these challenges and every single citizen has the right to do so. Lafont appeals to the evocative imagery of citizens in robes and suggests that contesting legislation at the level of the Supreme Court does not take questions out of the public sphere and into the legal domain but rather brings questions of right and constitutionality into the political domain. The focus is not on the judicial decisions which are often narrow and legalistic (Zurn 2020). The focus instead is on the public debate that is catalyzed by these challenges. And here Lafont uses the example of same sex marriage to suggest that the tide of public opinion turned partly it would seem by a change of framing in the public debate from an ethical question about the meaning of marriage to a constitutional question about right. Lafont argues that a debate about the meaning of marriage is subject to deep disagreement as participants draw on comprehensive values many of which may be anchored in religious convictions not shared by all citizens. Debate about constitutionality, by contrast, is structured in such a way that only appeals to liberal democratic principles of legality and right are appropriate. This she claims makes it possible to find agreement on fundamental questions of justice. I take a closer look at this argument in the next section. For now, I want to stress her claim that we should see the slow but steady development of a strong public support for same sex marriage, initiated by legal challenges, as an exercise in participatory deliberative democracy.

Lafont makes a strong case for seeing constitutional contestation and judicial review as a citizen led and citizen focused process. We are all potential petitioners with the right to directly challenge any and all law on the grounds that it violates my or our status as free and equal citizens. This challenge is not just about demanding a justification for law from elites, it is also more importantly about initiating a conversation in which we collectively engage in mutual justification. Lafont wants to convince us that long term public debates about foundational questions of justice are the place that citizens exercise democratic control. Thus her admonishment against shortcuts is not only a criticism of views that seek to bypass citizen participation, it is also a call to look at democratic politics as a long term process not measured in election cycles but over generations. There are no shortcuts to creating the political culture that can sustain rights and freedoms over time. Supreme court decisions can contribute to this ongoing process but they can't determine its outcome.

Right now in the US there are a growing number of constitutional challenges to same sex marriage on the grounds of religious free exercise. Lafont is absolutely correct to see these challenges as challenges facing citizens in thinking through, talking about, and justifying their collective understanding of rights. Judicial decisions will be handed down, but in the long run it will be the outcome of these public debates that underpins and protect those rights. 'The main way judicial review contributes to political justification is that it empowers citizens to call the rest of the citizenry to put on their robes in order to show how the policies they favor are compatible with the equal protection of the fundamental rights and freedoms of all citizenssomething which they are committed to as democratic citizens. It is in virtue of this communicative power that all citizens, whether religious or secular, can participate as political equals in the ongoing process of shaping and forming a considered public opinion in support of political decisions that they can all own and identify with. This is what a democracy without shortcuts looks like' (2019: 240).

I see this argument as a contribution to deliberative constitutionalism (Chambers 2017). Often deeply influenced by Habermas, these constitutional theories see constitution making, changing, and reforming as ideally the product of inclusive popular deliberation over time. Citizens must take ownership of the constitution and 'the task of interpreting and elaborating the system of rights poses itself anew for each generation; as the project of a just society, a constitution articulates the horizon of expectations opening on an ever present future' (Habermas 1996: 384). The image of citizens in robes captures both the democratic nature of this process as well as its focus on fundamental rights and the impartial and public perspective needed to adjudicate questions of fundamental rights. Judicial review then creates the opportunity for citizens to review, question, challenge and ultimately turn back popularly enacted legislation. Rather than seeing judicial review as a handful of appointed judges squaring off against democratic majorities, Lafont sees judicial review as citizens deliberatively reflecting on their own actions from the point of view of justice and right. This is, as I have said, a powerful democratic re-reading of judicial review. But citizens only occasionally are asked to put on the robes of constitutional deliberation and now I want to turn to the picture of ordinary non-constitutional politics presented in this book. What happens when citizens do not don the robes of impartiality and pursue less lofty goals and aims? Here it seems to me that Lafont cedes everyday politics to non-deliberative forces. What I suggest in the next section is that in insisting that public reason is a defining feature of deliberation, Lafont narrows the scope and relevance of deliberative democracy to constitutional questions.

\section{Participatory Deliberative Democracy as Constitutional Contestation}

In order to reconstruct this stronger version of the relationship between judicial review and deliberative democracy, we need to go back to the beginning of her argument. Lafont argues that the democratic ideal involves more than instantiating political equality; it also involves facilitating popular control. Citizens themselves have to be or feel themselves to be in the driver's seat. According to Lafont, many democratic theories circulating now often (sometimes unintentionally) deprive citizens of this role. Individual citizens are asked to defer to majorities, or experts, or minipublics. Thus Lafont introduces the problem of blind deference. And her position is participatory because she argues that it is undemocratic to bypass citizens in this way and ask for blind deference. 
Blind deference signals a lack of control. Blind deference undermines the claims of self-government. What then would reinstate control and facilitate self-government? Lafont endorses, as do I, a Habermasian picture of democratic control that involves a feedback loop between opinions and will formation in an open and dynamic public sphere. This feedback loop connects the interest, concerns, and claims of ordinary people to political decisions taken at the center in such a way that the 'processes of political opinion and will formation ... effectively influence and shape the laws and policies to which (citizens) are subject' (2019: 24). We must insure that 'political decisions are (and remain) responsive to the interests, views, and policy objectives of citizens as a whole' (2019: 164). I endorse this vision of democratic control but in some ways the direction that Lafont takes her argument in the final chapters of the book betrays the democratic ideal of self-government she articulates in the first half.

The feedback loop conception of an ongoing communicative interaction between the center and the periphery requires some concrete picture of ways that citizens' considered opinions can feed into the processes of law making. Lafont does not offer such a picture; instead she offers a picture of the institutional opportunity every citizen has to discursively challenge a law if it fails to track or reflect their deepest concerns: 'such an approach requires institutions to be in place such that citizens can contest any laws and policies that they cannot reasonably accept by asking that either proper reasons be offered for them or that they be changed. To the extent that such institutions are available to all citizens, even to those who happen to find themselves in the minority, they can see themselves as equal members of a collective political project of self-government' (2019: 16-17). For Lafont, the institution that best embodies this ideal of selfgovernment is judicial review of democratically enacted laws. While I am in full agreement that constitutional contestation is best understood through the lens of deliberative democracy and that it is an important mechanism of democratic accountability, I also think that deliberative democracy offers a potentially fuller view of self-government than constitutional contestation. Which is to say that deliberative democracy can offer a picture of democratic self-government that focuses more up-stream on the legislative process itself rather than downstream at the constitutional challenge of unjust laws.

How did Lafont get from democratic control to constitutional contestation? It seems to me that Lafont goes off track when she tackles the feasibility question. How realistic is it to think that citizens at large will engage in real deliberation? Lafont notes that 'this ideal of public deliberation as a process of mutual justification is often criticized for being too demanding' (176). It is too demanding to think that ordinary citizens will engage in serious attempts at mutual justification for all the laws and policies under which they live. This is especially true if we think that mutual justification commits participants to employ only sharable reasons. This leads Lafont to restrict the scope of mutual justification to constitutional issues. The thought here is that even if we cannot imagine ordinary citizens engaging in public reasoned debates about all legislation and public policy, we can perhaps imagine citizens rising to the occasion and engaging in an over-time debate about fundamental questions of right and justice that stand at the very core of the political association. I want to offer a different vision deliberative democracy, one that does not limit its scope to constitutional contestation.

Deliberative democracy has been plagued with the feasibility question from day one. If we think of deliberation as an individual level practice that ideally involves face-to-face dialogue, then scaling up to mass democracy seems impossible. This has led many theorists interested in the application of deliberative democracy to mass democracy to move in the direction of a system approach (Mansbridge \& Parkinson 2012). This approach looks at deliberation from a procedural and disaggregated perspective in which there is a significant functional division of labor. Not every citizen is expected to engage in high end deliberation but ideally the system functions as a whole to facilitate the circulation of reasons, justifications of laws, and the criticisms of policy, and the feedback mechanism necessary to produce considered opinion and will formation. I endorse a Habermasinfluenced version which identifies three levels of political communication: institutionalized discourse, media-based mass communication, and everyday communication in civil society. At the first two levels, elites are the dominant 'deliberators' but the system if well-functioning produces a feedback loop in which ordinary citizens, articulating real problems and concerns bubbling up from civil society, set the agenda (Habermas 2009; Chambers 2017). ${ }^{4}$ That agenda is refined and debated at the higher up levels and then is picked up again in everyday talk and becomes part of the process of opinion and will formation. The feedback loop (if working well) plus a plural, competitive, critical, and free mass media ensures that citizens at large are not manipulated by elites or left only the option of blind deference. This is a complex picture which I will not defend at any length here. For now, I only wish to highlight the fact that in this picture, deliberation offers a functional framework of analysis rather than referring to an individual level practice. As Habermas articulates it 'only across the full scope of the process of legitimation can 'deliberation' perform the filtering function which justifies the supposition that the process of political will formation fishes the reasonable elements of opinion formation out of the murky streams of political communication' (2009: 160). This picture of democratic government has abandoned a demanding and uniform participatory ideal of citizenship in favor of a realistic division of labor view. Every citizen has equal standing in this process but not every citizen has the same role to play in the system.

In contrast to the systemic approach to deliberative democracy, Lafont wants to stay with a participatory view of deliberative democracy in which we can imagine each individual potentially engaging in mutual justification in roughly the same way (although some more actively than others). This individual level analysis is made even more demanding by Lafont's instance that mutual justification be governed by a public reason constraint and hold out the possibility of full consensus. Thus the 
criterion of democratic legitimacy that deliberative democrats endorse' is one in 'which citizens ought to justify the imposition of coercive policies on one another with reasons that everyone can reasonable accept' (2019: 195). Deliberative democracy 'stands or falls with the ability to explain how public deliberation can bring about substantive agreement without exclusion under conditions of pluralism' (2019: 193).

Where can we possibly imagine citizens engaging in this demanding form of justification? Rawls appealed to the moral self-restraint of citizen-a duty of civility-and hoped that we would live up to this ideal. Lafont takes a different route. Rather than rely on the civic virtue of citizens, she suggests that certain institutional contexts will, in a sense, force citizens to stay within the bounds of public reason. Thus she seeks to 'identify those features of democratic institutions and practices that enable processes of opinion and will-formation to be so structured that disagreements can be reasonably overcome among citizens with different views, interests, values and so on' (193). And it turns out that constitutional contestation made possible by judicial review is the democratic institution that achieves this goal. It achieves this goal because everybody needs to argue in the language of rights, equality, and freedom. Thus, even Evangelical Christian challengers to same sex marriage must argue in the moral language of the constitution when engaged in public constitutional contestation. Here is where Lafont insists that her view is not moral but institutional. By this she means that we do not have to rely on the moral good will of citizens to exercise a 'duty of civility.' Instead, the institutional constraints and expectations of constitutional discourse will do the job for us. This too she claims adds to the theory's feasibility.

Despite the move to institutional rather than moral constraint and the narrowing the scope of deliberation to constitutional contestation, this is still a very demanding view of deliberation. I want to return to two features of this view. The first is that the idea that legitimacy of laws rests on citizens justifying those laws with reasons that are acceptable to all and second the idea that deliberation must be able to produce 'substantive agreement without exclusion under conditions of pluralism.' I agree with Lafont that deliberative democrats share a view of legitimacy that begins with the idea that legitimate laws are the outcome of properly structured deliberative procedures. Further, some (but not all) theorists also embrace agreement or consensus as the proper telos of deliberation. But even with the regulative ideal of agreement or consensus standing at the highest end of the legitimation continuum, in the real world, full agreement (with no remainder) is impossible to achieve; every empirical consensus is flawed, fallible, corrigible and characterized by exclusions. Given this, the legitimacy of laws from a deliberative democracy point of view, it seems to me, cannot be measured by looking at any given consensus or empirically reached agreement, nor is legitimacy ascertained via a hypothetical question of what would citizens agree to in deliberation, nor do we ask if a law is supportable by public reasons.

Legitimacy is best assessed, it seems to me, through an evaluation of the procedural/deliberative conditions under which public opinion and will are formed and channeled into authoritative decisions. On this view then we look at the full system of democratic institutions (and not just judicial review) from the point of view of their potential to structure a certain type of conversation. If we look at democracy this way, then rights and freedoms, our equal opportunities to participate and speak, the fair regulation of the public sphere, free and fair elections, the openness of civil society, inclusion of multiple voices, the expansion of deliberative forums, and the accountability of our representatives (to name only some of the institutions in play) can all be read in deliberative democratic terms, that is, as procedural conditions for the production of legitimate law. Although legitimate legislation is what people would agree to in a deliberation, we have no independent access to what that agreement would be. Thus legitimacy is procedural in the sense that it is imbued in the procedural possibility to raise arguments, challenge reasons, put forward claims and have these influence and shape legislation. Promoting optimal deliberative conditions such the circulation of reliable information, publicizing and inclusion of multiple voices, and the equal status of all participants are valuable deliberative democratic goals even when the question on table is not a question of justice for which we should be seeking a rational consensus. The legitimacy of every majority vote is tied to the robustness, inclusiveness and egalitarian conditions of the public deliberative processes that proceed the vote.

\section{Conclusion}

By insisting that public reason is a defining feature of public justification and suggesting that public reason will only dominate under the institutional constraints of constitutional discourse, Lafont restrict deliberative democracy to constitutional questions. Only citizens in robes, which is to say citizens striving for neutrality in debating and forming opinions about constitutional rights, engage in participatory deliberative democracy.

This view leads to a type of constitutional dualism not dissimilar to Bruce Ackerman's dualism. Dualism insists on a differentiation between higher law-making and ordinary law-making. The line is quite bright in Ackerman who seems to have a rather pessimistic view of the deliberative potential of ordinary law-making but an uplifting narrative about constituent power exercised over time and through history in extraordinary moments of constitutional mobilization (Ackerman 1991). At these moments one sees the 'mobilized deliberation' of engaged and self-conscious publics undertake the transformative politics of reinterpreting the constitution (Ackerman 1991: 290). Unlike Ackerman, Lafont does not see constitutional politics as episodic. Rather, she sees constitutional contestation as an ongoing permanent process that is part of the democratic process. But like Ackerman, it runs parallel to and is separate from ordinary politics. And also like Ackerman this type of politics leads to change and transformation only in the very long term. This type of democratic control is not measured in election cycles or administrations but in decades, eras, and perhaps even centuries. We are, after all, still trying to see the civil 
rights movement through with no end in sight. While I sign on to the idea of constitutional politics as democratic politics, I also think that deliberative democracy has much to say about everyday politics, ordinary law-making, and the anarchic public sphere of mass democracies. But everyday politics, ordinary law-making, and the public sphere cannot achieve nor should they seek to achieve substantive agreement without exclusion under conditions of pluralism.' Lafont makes a rather stark contrast between deliberation on the one hand, and bargaining, compromise, and negotiation on the other (2019: 193). She has no problem with bargaining, compromise, and negotiation. These are useful methods, along with majority voting, to resolve everyday political problems. But they are not deliberation; deliberation is appropriate to answer questions about rights not everyday wrangling over policy. This seems to me to drastically narrow the political relevance of deliberative democracy.

\section{Notes}

${ }^{1}$ For a definition and critique of populist constitutionalism see Müller (2017) and Chambers (2019).

${ }^{2}$ Lafont claims that she rejects the moral view of public reason because although she endorses a constraint on reasons she understands that constraint to be enforced through institutional expectations rather than moral motivation of the deliberators. In this way her theory does not depend on the moral virtue of individuals. This still strikes me as a moral view however as public reason involves a type of impartiality.

${ }^{3}$ Habermas does exclude religious reasons (but not comprehensive reasons) from legislative deliberation and this certainly looks like a public reason constraint (2008: 128).

${ }^{4}$ Lafont also endorses this Habermasian feedback loop in her book (pp. 172-173) but as I argue below, she does not appear to embrace the procedural division of labor that accompanies this view.

\section{Competing Interests}

The author has no competing interests to declare.

\section{References}

Ackerman, B. (1991). We the people: Foundations vol I. Cambridge, MA: Harvard University Press.

Bellamy, R. (2007). Political constitutionalism. Cambridge, MA: Cambridge University Press. DOI: https://doi. org/10.1017/CBO9780511490187

Chambers, S. (2017). Balancing epistemic quality and equal participation in a systems approach to deliberative democracy. Social Epistemology, 31(3), 266-276. DOI: https://doi.org/10.1080/02691728.2017.1317867

Chambers, S. (2019). Democracy and constitutional reform: Deliberative versus populist constitutionalism. Philosophy and Social Criticism, 45(9-10), 1116-1131. DOI: https://doi.org/10.1177/0191453719872294

Dryzek, J. (2010). Foundations and frontiers of deliberative governance. Oxford: Oxford University Press. DOI: https://doi.org/10.1093/acprof:oso/978 0199562947.001.0001
Eisgruber, C. (2001). Constitutional self-government. Cambridge, MA: Harvard University Press.

Ferejohn, J. (2008). The citizen's assembly model. In M. Warren \& H. Pearse (Eds.), Designing deliberative democracy: The British Columbia citizens' assembly (pp. 192-213). Cambridge: Cambridge University Press.

Ferejohn, J., \& Pasqual, P. (2002). Constitutional courts as deliberative institutions. Towards an institutional theory of constitutional Justice. In W. Sadurski (Ed.), Constitutional justice, east and west (pp. 21-36). The Hague: Kluwer Law International.

Gutmann, A., \& Thompson, D. (1996). Democracy and disagreement. Cambridge, MA: Harvard University Press.

Habermas, J. (1996). Between facts and norms: Contributions to a discourse theory of law and democracy, translated by W. Rheg. Cambridge, MA: MIT Press. DOI: https://doi.org/10.7551/mitpress/1564.001.0001

Habermas, J. (2008). Between naturalism and religion, translated by C. Cronin. Cambridge, MA: MIT Press.

Kramer, L. (2004). The people themselves: Popular constitutionalism and judicial review. New York: Oxford University Press.

Lafont, C. (2019). Democracy without shortcuts: A participatory conception of deliberative democracy. Oxford: Oxford University Press. DOI: https://doi. org/10.1093/oso/9780198848189.001.0001

Mansbridge, J. (1999). Everyday talk in deliberative systems. In S. Macedo (Ed.), Deliberative politics: Essays on democracy and disagreement (pp. 211-239). New York: Oxford University Press.

Mansbridge, J., \& Parkinson, J. (Eds.) (2012). Deliberative systems. Cambridge: Cambridge University Press. DOI: https://doi.org/10.1017/CBO9781139178914

Mendes, C. H. (2013). Constitutional courts and deliberative democracy. Oxford: Oxford University Press. DOI: https://doi.org/10.1093/acprof:oso/9780 199670451.001.0001

Müller, J. (2017). Populism and constitutionalism. In C. R. Kaltwasser, P. Taggart, P. O. Espejo \& P. Ostiguy (Eds.), The Oxford Handbook of Populism (pp. 590-606). Oxford: Oxford University Press. DOI: https://doi. org/10.1093/oxfordhb/9780198803560.013.28

Rawls, J. (2005). Political liberalism. Expanded edition. New York: Columbia University Press.

Tushnet, M. (2000). Taking the constitution away from the courts. Princeton, NJ: Princeton University Press. DOI: https://doi.org/10.1515/9781400822973

Waldron, J. (2006). The core case against judicial review. The Yale Law Journal, 115(6), 1346-1406. DOI: https:/ / doi.org/10.2307/20455656

Warren, M. (2007). Institutionalizing deliberative democracy. In S. W. Rosenberg (Ed.), Deliberation, participation, and democracy: Can the people govern? (pp. 272-288). Basingstoke: Palgrave Macmillan. DOI: https://doi.org/10.1057/9780230591080_13

Zurn, C. F. (2020). Constitutional interpretation and public reason: Seductive disanalogies. In S. A. Langvatn, M. Kumm \& W. Sadurski (Eds.), Public reason and the courts (pp. 323-349). Oxford: Oxford University Press. DOI: https://doi.org/10.1017/9781108766579.013 
How to cite this article: Chambers, S. (2020). Citizens Without Robes: On the Deliberative Potential of Everyday Politics. Journal of Deliberative Democracy, 16(2), pp. 73-80. DOl: https://doi.org/10.16997/jdd.388

Submitted: 05 March 2020

Accepted: 11 June 2020

Published: 14 October 2020

Copyright: ( $) 2020$ The Author(s). This is an open-access article distributed under the terms of the Creative Commons Attribution 4.0 International License (CC-BY 4.0), which permits unrestricted use, distribution, and reproduction in any medium, provided the original author and source are credited. See http://creativecommons.org/licenses/by/4.0/.

W Journal of Deliberative Democracy is a peer-reviewed open access journal published by University of Westminster Press. 